\section{Michigan Technological

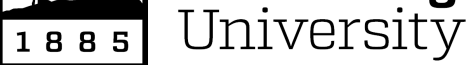

Michigan Technological University Digital Commons @ Michigan Tech

7-21-2012

\title{
Open-source Development of Solar Photovoltaic Technology
}

\author{
A. J. Buitenhuis \\ Queen's University - Kingston, Ontario \\ Joshua M. Pearce \\ Michigan Technological University
}

Follow this and additional works at: https://digitalcommons.mtu.edu/materials_fp

\section{Recommended Citation}

A. J. Buitenhuis and J. M. Pearce, "Open-Source Development of Solar Photovoltaic Technology", Energy for Sustainable Development, 16, pp. 379-388 (2012). http://digitalcommons.mtu.edu/materials_fp/31/ 
Published as: A. J. Buitenhuis and J. M. Pearce, "Open-Source Development of Solar Photovoltaic Technology", Energy for Sustainable Development, 16, pp. 379-388 (2012). DOI: http://dx.doi.org/10.1016/j.esd.2012.06.006

\title{
Open-Source Development of Solar Photovoltaic Technology
}

\author{
A. J. Buitenhuis ${ }^{1}$ and J. M. Pearce ${ }^{1,2^{*}}$
}

1. Queen's Applied Sustainability Research Group, Queen's University, 60 Union St. Kingston, ON K7L 3N6, Canada

2. Department of Materials Science \& Engineering and Department of Electrical \& Computer Engineering, Michigan Tech amorphous silicon nological University, 601 M\&M Building, 1400 Townsend Drive, Houghton, MI 49931-1295, USA

* Contact author: phone: 906-487-1466, email: pearce@mtu.edu

\begin{abstract}
The rise of solar photovoltaic (PV) technology as a driver of rural electrification in the developing world and a contributor to climate change mitigation suggests that innovations enhancing PV efficiency and scalability could make considerable strides in reducing both poverty and greenhouse gas emissions. The nearly global access to the solar resource coupled to innovation-driven decreases in the costs of PV provides a path for an renewable energy source to accelerate sustainable development. Open-source software development has proven to produce reliable and innovative computer code at lower costs than proprietary software through sharing development responsibility with a large community of invested individuals. Concepts of open-source design have been applied to other fields in an attempt to reap the same benefits realized within software development; however, applying open-source strategies to solar PV research is uncommon. This paper reviews and examines how open-source design can be utilized to catalyze rapid innovation in the PV industry. The results show how successful open design and development methods can be created and utilized by identifying business models that provide PV researchers, turnkey suppliers and solar PV module manufacturers with the opportunity to utilize opensource design principles to accelerate innovation.
\end{abstract}

Keywords: commons; open design; open source; public domain; solar energy; solar photovoltaic

\section{Introduction}

There has been an extremely rapid expansion of the solar photovoltaic (PV) industry from 1990, when PV module production was but 46 MegaWatts (MW, equivalent to $10^{6}$ watts) to a more than 500fold surge to 23.5 GigaWatts (GW, $10^{9}$ watts) in 2010 (Jäger-Waldau, 2011). This makes solar PV one of the fastest-growing industries at present, which is necessary as it has been argued to be one of the most promising responses to accelerating global climate change (Hoffert et al., 2002; Kenny, et al., 2010; IEA PVPS, 2009; IEA, 2010; Pearce, 2002; Solarbuzz, 2009). Solar PV has the potential to play a significant role in this shift towards an energy economy for both the developing and developed world that is not only more sustainable, but can provide a major contribution to $\mathrm{CO}_{2}$ emissions reductions (Foley, 1995; IEA PVPS, 2009; IEA, 2010, Kenny et al., 2010). However, the potential of solar PV has not been completely realized. Most of the barriers that prevent solar PV from reaching its full potential are primarily economic in origin. This barrier is lowering as the levelized cost of solar electricity continues to decline and become economically competitive in an ever growing list of regions around the world (Branker, et al., 2011). However, economic competitiveness with conventional sources of electricity can also be obtained through innovations in PV technology including improvements in performance and manufacturing. Areas open for technical innovation, which would improve PV 
Published as: A. J. Buitenhuis and J. M. Pearce, "Open-Source Development of Solar Photovoltaic Technology", Energy for Sustainable Development, 16, pp. 379-388 (2012). DOI: http://dx.doi.org/10.1016/j.esd.2012.06.006

economics include: i) increased PV module efficiencies (Green, 2003; IEA, 2010) ;ii) improved power processing, inverter performance and lifetimes (Petrone, et al, 2008; IEA, 2010); iii) expanded storage capacities, charge cycles, reduced materials, and improved controls (Manz, et al., 2008; IEA, 2010); iv) restructuring electric utilities to accommodate intermittent supply both with technical and regulatory upgrades (Ilic, et al., 2007; IEA, 2010) such as creating more appropriate utility rate structures (Pearce and Harris, 2007). This paper examines how rapid technological innovations could occur, and how such innovations could lead to the mass deployment on the Tera-Watt-level ( $10^{12}$ watts) of solar PV in both the industrialized and developing world.

In 2009, the United States Secretary of Energy, Steven Chu, suggested a strategy to encourage the growth of renewable technologies: "If countries actively helped each other, they would also reap the home benefits of using less energy. So any area like that I think is where we should work very hard in a collaborative way - by very collaborative I mean share all intellectual property as much as possible" (Revkin and Galbraith, 2009). Following Chu's recommendation, this paper critically examines how open-source design, which is a method based around the sharing of intellectual property (IP) forged in the software industry, could be applied in the solar PV industry. It then examines how this shift in technology design methodology can enhance the rate of innovation and development of solar technologies to mitigate climate change and bring renewable electricity to the developing world. This is achieved by an investigation of open software development, the solar PV industry, and then an exploration of business models that would facilitate collaboration and sharing within the PV industry.

\section{Methods}

This paper examines how open-source design can be utilized to catalyze rapid innovation in the PV industry. First, open-source and open design are defined and the science commons is examined for its use of open concepts to develop knowledge. As part of this discussion, the open-source software movement and other industries using open design/open-source hardware are studied to identify its historical evolution and benefits. Next, the growth, structure, and breakdown of the thin-film solar-PV industry is examined and compared to the software industry to better understand how open-source development could be applied to the solar-PV industry. While there are differences in the way that open-source software and open solar PV research is conducted, this paper identifies and critically evaluates methods through which open-source principles could be utilized to encourage innovation, enabling solar PV to realize its full potential. Being that determining feasible and profitable business models is the largest barrier to the adoption of open design (Hecker, 1999), this paper presents four appropriate business models for open PV development. These were chosen (in Section 5) from the available models within open-source software because of their ability to overcome known challenges for transfer to open-source hardware (Stallman, 1999) and their ability to meet the criteria needed to match open-source development in the PV industry (outlined in Section 4). Specifically from the literature review of open-source, open design, openness and industry, and open-source business models current applications are identified, barriers to implementation are highlighted, and possible solutions to creating business models are established. The models are examined based on their past successes, applicability to different types of solar firms, profitability, and openness.

\section{Background}

\subsection{Open Source}


Published as: A. J. Buitenhuis and J. M. Pearce, "Open-Source Development of Solar Photovoltaic Technology", Energy for Sustainable Development, 16, pp. 379-388 (2012). DOI: http://dx.doi.org/10.1016/j.esd.2012.06.006

Open source refers to a method of development in the software industry that allows software code to be published for other users to see, modify, and use, instead of being copyrighted or patented (Mockus et al., 2002). However, the open-source concept and commons-based approach has existed in academia (Benkler, 2004) long before being applied to computer software. Freely publishing results provides scientists with credibility and respect and in exchange, the remainder of the scientific community can use the knowledge to expand, develop, and improve upon it using their own ideas (Bergquist and Ljungberg, 2001) ${ }^{1}$. To many academics, publishing work in the commons is more important than patenting their ideas. Albert Einstein, one the most influential and innovative scientists of the twentieth century authored over 300 publications accessible to the scientific community, but holds only twelve patents (Einstein Archives Online, 2003).

The open-source software movement has created a radical shift in the way that software companies do business and has come to be seen as a major competitor to the proprietary software industry (Pykäläinen, 2007). When software is open source, there are few restrictions on the code ${ }^{2}$, which allows it to be modified, changed and improved based on the needs of the user. In his seminal essay on open-source concepts, The Cathedral and the Bazaar, Raymond (1999) points out that "given enough eyeballs, all bugs are shallow", meaning that all problems in software development becomes simple to solve once enough users participate in the development. Thus, one of the main advantages of open-source software is that with many users contributing to the development of the code, improvement and innovation of the software is trivial. Additional benefits of open-source software include:

- Decreased research and development (R\&D) costs (Lakhani and von Hippel, 2003)

- More reliable and robust programs (Bonaccorsi and Rossi, 2003)

- Increased innovation within the developments (Kogut and Metiu, 2001)

- Decreased dependency on monopoly suppliers (Bruns, 2000; Kogut and Metiu, 2001)

\subsection{Open-source Design}

The ability to open-source a design is possible with products other than software. In contrast to the case of software, the "source" of an open hardware product would be the designs, specifications, materials list, and all other related technical knowledge. Thus, open-source design or open design is when a product's designs and specifications are published openly and not subject to IP protection. While software code is typically protected through licensing schemes and copyrights, hardware is protected through patenting.

However, there are serious doubts surrounding the ability of patents to enhance innovation. Jaffe's (2000) empirical investigation of patent policy changes in the United States between 1980 and 2000 concluded that is not possible to determine if the benefits of increased innovation through strengthening patent laws outweigh the costs, nor is it clear that patent policy changes in the past 20 years have significantly affected technology transfer. Both Schankerman's (1998) empirical study of patenting in different technological fields in France and Jaffe (2000) concluded that patents are not the most significant source of return for incentivizing R\&D. Mazzoleni and Nelson (1998) go further by stating

\footnotetext{
${ }^{1}$ With many scientific journals, access to information is acquired with the payment of a fee, and is therefore not completely open in the sense that it is free for anyone to access. However, open access journals are rapidly becoming more prominent in most academic disciplines (Antelman, 2004).

${ }^{2}$ The amount of restrictions placed on a software packages is determined by the type of license. For a thorough description of software licenses, see Lerner and Tirole (2005).
} 
Published as: A. J. Buitenhuis and J. M. Pearce, "Open-Source Development of Solar Photovoltaic Technology", Energy for Sustainable Development, 16, pp. 379-388 (2012). DOI: http://dx.doi.org/10.1016/j.esd.2012.06.006

that the strengthening of IP laws may actually hinder technological development in some cases. Theoretical modeling has rendered similar results. For example, Torrance and Tomlinson (2009) found through a multi-user interactive simulation that technologies designed through a completely open process had much higher rates of innovation, productivity and social utility than products designed in both a completely closed environment and in a mix of open and closed design methods. It is, therefore, clear that alternatives to the patent system that focus on the weakening or removal of IP protection should be considered.

\subsection{Openness and Industry}

There have now been investigations into applications of open design and open innovation in industry. Garud and Kumaraswamy (1993) studied the Sun Microsystems open systems strategy from the 1980s and 1990s, when access and use of the firm's technical knowledge and entry into its market were both encouraged. Sun Microsystems went from 15\% of the workstation market share compared with industry leader Apollo's 43\% market share to lead the industry in 1989 with $28 \%$ of the workstation market share (Garud and Kumaraswamy, 1993). In addition, Benkler (2004) makes the case that strong IP protection and patents slow the pace of innovation at universities and institutions in the United States. The effects of IP on the rate of innovation have also been examined with respect to biomedical research, where researchers have found that patents and other forms of IP protection are slowing innovation due to the tragedy of anti-commons (Heller and Eisenberg, 1998). This is particularly important when a new drug or treatment has the possibility to save lives in the developing world, but cannot be mass-manufactured due to patents and copyrights. Thus, some have prosed opensource strategies to solving medical problems in the developing world (Kapczynski et al., 2005; Maurer et al., 2004). Finally, the application of open sourcing in fields such as nanotechnology (Bruns, 2001; Mushtaq and Pearce, 2012) and appropriate technology for international sustainable development (Pearce and Mushtaq, 2009; Buitenhuis et al., 2010) were found to be promising. However, there has been no similar examination of the application of openness in solar PV.

\subsection{Solar Photovoltaic Industry}

To understand how open sourcing may be applied to PV manufacturing, one must understand the current state of the solar PV industry. The International Energy Agency (IEA) has found that PV is a commercially available and reliable technology with a significant potential for long-term growth in nearly all world regions (2010). The IEA has predicted solar energy will provide over half of global energy demands by 2060 (Sills, 2011). To meet this goal, the current aggressive growth previously mentioned will need to be maintained. In particular, there has been an substantial growth of $123 \%$ in the thin film PV industry (made up of amorphous silicon [a-Si]-, cadmium telluride [Cd-Te]- and copper indium diselenide [CIS]-based cells) (Solarbuzz, 2009). This is largely due to the sharp increase in turnkey manufacturing suppliers - particularly of a-Si. Turnkey suppliers sell equipment to module manufacturers, which enables businesses to quickly enter the PV market with reliable products in high demand. There are now more than a dozen such suppliers, with the top three having combined revenues of over one billion dollars (VLSI Research Inc., 2009).

The increase in suppliers is an important trend because although thin film PV is nearing grid parity in some areas like Japan, in order for the technology to become economically feasible over large geographic areas, the cost per installed unit power $(\$ / \mathrm{W})$ must decrease (Branker, et al., 2011). This is possible by either increasing the efficiency of the cells, which would provide more electricity (kW-hrs) 
Published as: A. J. Buitenhuis and J. M. Pearce, "Open-Source Development of Solar Photovoltaic Technology", Energy for Sustainable Development, 16, pp. 379-388 (2012). DOI: http://dx.doi.org/10.1016/j.esd.2012.06.006

generated per installed $\mathrm{W}$ per year, or reducing the cost of production and thus the $\$ / \mathrm{W}$ installed costs. To do the latter, module production costs would have to be reduced through economies of scale within large turnkey manufacturing suppliers and industrial symbiosis (Keshner and Arya, 2004; Pearce, 2008). However, it is possible to achieve both goals (improved efficiency and manufacturing efficiency) by introducing an open R\&D model to the thin film PV industry. If firms were able to share their IP and collaborate and contribute to the research of others, it is likely that lessons learned from different turnkey suppliers and manufacturers would speed up the rate of innovation within the thin film PV industry, both to improve module efficiencies as well as to develop ways of manufacturing modules more cost-effectively.

Currently, the solar PV industry uses primarily traditional proprietary models of design and innovation. Innovations in the solar industry are created within the R\&D labs of universities and research centres, turnkey suppliers, and manufacturers. These universities and research centres work together with some suppliers and some manufacturers; however, the fast pace of innovation and rapid growth forces companies to fiercely maintain their IP (Margolis et al., 2006). Although research into thin films has been taking place for the past 30 years, a strong resurgence of thin film PV in the 1990s has made it into a relatively new industry (Shah et al., 1999). Unlike the nanotechnology or biomedical fields, there is no literature regarding IP protection as a large barrier for innovation. However, evidence that patents may start to act as barriers can be found in examining the Swiss firm Oerlikon Solar AG's recent thin film module patent ruling. Oerlikon had exclusive rights on a patent covering the manufacturing process for micromorph thin film modules ${ }^{3}$ and filed a patent infringement lawsuit against a module manufacturer, Sunfilm AG (Papathanasiou, 2009). If the patent had not been challenged and overturned, research and innovation would have slowed down in the a-Si thin film field due to the large monopoly that Oerlikon would have held over all companies. In this way both the threat of and actual patent infringement litigation hinder rates of innovation.

\section{The Solar Photovoltaic Industry and Open-Source Development}

When applying open principles to the PV industry it is important to understand the subtle differences between software and hardware in order to successfully apply open business models to solar manufacturing. Figure 1 depicts a map of open-source software development. The 'instigator' inputs the basics of the code and manages any other changes or modifications to that code. The users contribute to the code in order to improve upon existing sections and create new applications and tools. The ability for open-source design to be successful in the software industry has been attributed to:

- Gift culture: Those who utilize the contributions of others to a certain code feel they need to reciprocate by also contributing to the code. Those who make the most important or valuable contributions are seen to be the most powerful (Bergquist and Ljungberg, 2001).

- Hacker community: There is a community of people that congregate in forums and spaces on the Internet to talk, 'debug' problems, and share ideas related to computer programming. Often, 'hackers' participate in an open-source project because they enjoy the project, and because they may see real or perceived benefits (i.e. job opportunities, professional credibility) from this participation (Bonaccorsi and Rossi, 2003).

\footnotetext{
${ }^{3}$ The micromorph solar cell is a tandem solar cell made of two layers: a-Si and microcrystalline silicon. These two materials have nearly optimal bandgaps for a double junction solar cell under AM1.5 illumination (Meier et al., 1998).
} 
Published as: A. J. Buitenhuis and J. M. Pearce, “Open-Source Development of Solar Photovoltaic Technology”, Energy for Sustainable Development, 16, pp. 379-388 (2012). DOI: http://dx.doi.org/10.1016/j.esd.2012.06.006

- Modularity: Portions of the system can be broken down into small, easily manageable pieces, and different developers can work separately on these sections. This facilitates the coordination of a number of simultaneous developers (Bonaccorsi and Rossi, 2003).

These factors enable open software development to be highly innovative and reliable. The user and the developer of the software become one user-developer, as shown in Figure 1, making the products more applicable to themselves. This is different than the traditional software development model, shown in Figure 2, where there is a hierarchical, unidirectional relationship between developer and user. There are many possible benefits of open design specific to the solar industry, which include:

- Increased speed (from more innovators working with more information) and quality (from greater peer review) of technological innovation, leading to a decrease in cost/Watt of modules

- Decreased R\&D costs due to sharing expertise and equipment

- Faster adoption of latest technologies by manufacturers

- Increased efficiency of technological design processes, since less time is spent protecting IP However, basic economic barriers exist to solar PV firms adopting open-source technologies. First, if a firm opens its designs, its competitors have the ability to use the designs to improve their own products. Second, opening PV designs would lower the barriers to enter the PV market for start-up firms (Pomerantz, 2000). The increased competition from both these types of PV firms would decrease the amount of funding that could be applied to R\&D.

In addition to economic barriers, there are clear structural differences between the software industry and the solar industry. A schematic diagram of the solar industry is shown in Figure 3 and can be compared to Figures 1 and 2 to better under the structural differences. Here the 'user' is the home owner who purchases a solar module. This user does not have the expertise needed to have the same type of interaction with the design of the module as a software user and thus no user-developers. At the same time, the PV industry has a weak hacker community, primarily made up of academic researchers and corporate scientists congregating at academic conferences. This weakness would tend to discourage the development of the necessary gift culture. Finally, PV research/design does not possess a high degree of modularity, although some technical challenges can be attacked independently and then solutions can be scaled across the industry (e.g. optical enhancement).

In order to apply open-source principles to the solar industry then, open design for solar PV must be re-conceptualized to account for these barriers. Structurally, development of technologies in the solar PV industry occurs within the top three levels shown in Figure 3: the university and research centers, the turnkey suppliers and the manufacturers. Openness could be created not between users and developers, but among the different developers (government and university research centers, equipment suppliers and manufacturers). The gift culture must be created within the market through business models and funding structures allowing or enhancing open design principles. Within these businesses and models, communities similar to the robust hacker community would be created and nurtured to contribute to the growth and development of the field.

\section{Business Models}

A business model describes the rationale of how an organization creates, delivers, and captures economic value, although in can also include social or other forms of value (Hedman and Kalling, 2003; Zott, et al., 2010). Companies that distribute open-source software can not depend on control of the source code for their business model and most use non-traditional models to provide sources of 
Published as: A. J. Buitenhuis and J. M. Pearce, "Open-Source Development of Solar Photovoltaic Technology", Energy for Sustainable Development, 16, pp. 379-388 (2012). DOI: http://dx.doi.org/10.1016/j.esd.2012.06.006

revenue (Krishnamurthy, 2005). A useful definition of business model in the open-source context is made up of three components: i) value (i.e. value proposition for customers), ii) revenue, and logistics (Mahadevan, 2000).

After review of available open-source business models (Bonaccorsi and Rossi, 2003; Bonaccorsi et al., 2004; DiBona et al., 1999; Fink, 2002; Hecker, 1999; Krishnamurthy, 2005; Mahadevan, 2000; Mockus et al., 2002; Mulgan et al., 2005; O'Reilly, 2007; Pomerance, 2000; Raymond, 1999; Tuomi, 2005; Zott et al., 2010), four business models are proposed that match the criteria laid out in Section 4 and are examined critically to identify the opportunities and challenges of each model. The first two - the partnership model and the franchise model - are examples of systems that could operate within the current industry framework, but that would enable sharing of IP and collaboration. The third - the secondary industry model - is a method that could be used to shift the PV industry into a more open environment. Finally, the fourth model examines the possibility of a radical shift with the PV industry to an open way of design.

\subsection{Partnership Model}

One way that open design methods could be expanded in the PV industry is through the sharing of IP within a partnership where members come together in order to share lessons learned and work together on challenges. Within these partnerships, not only research, but complementary assets such as testing equipment and facilities could be shared.

Figure 4 shows a schematic diagram of a general partnership model as it would appear in the context of the solar PV industry. All of the organizations within the dotted circle are participating in the partnership agreement. The arrows beginning with circles represent funding from outside the partnership. As with Bruns's (2001) 'producer coalition', such a partnership could be commissioned by a group of manufacturers to solve a specific problem within the field (i.e. the Staebler-Wronski Effect (SWE)- light-induced degradation of a-Si-based solar cells ${ }^{4}$ ) or it could be funded fully or in part by government agencies wishing to influence the direction of industry. In Figure 4, the dashed arrows show IP within the dotted circle being shared between universities and research centers, turnkey suppliers and manufacturers.

This partnership model has already been applied directly in the U.S. under the Thin Film Partnership Program (TFPP), which is examined here to identify the complexities within open partnerships. The TFPP, funded by the National Renewable Energy Lab (NREL) and started in 1992, aimed to improve "the efficiency and reliability of emerging thin-film PV technologies through collaboration among industry, national laboratories, and universities" (Margolis et al., 2006). The program focused around the following five research areas: a-Si, CIS and related materials, CdTe, environment, safety, and health (ES\&H), and module reliability. It had five teams comprising of any companies, universities and research centers specializing in the team's topic (NREL, 2008). Throughout the partnership, team meetings were held where research institutions presented findings and shared challenges. Companies and university centers also submitted quarterly reports to NREL staff, which were to be shared amongst the other team members. ${ }^{5}$

Within the TFPP, IP was deemed essential by PV companies to maintain their competitive

${ }^{4}$ For more information see the SWE literature (Staebler and Wronski, 1977; Wronski, et al., 2002; Wronski, et al., 2004).

${ }^{5}$ Correspondence with B. von Roedern, senior project leader with the TFPP of NREL. 
Published as: A. J. Buitenhuis and J. M. Pearce, "Open-Source Development of Solar Photovoltaic Technology", Energy for Sustainable Development, 16, pp. 379-388 (2012). DOI: http://dx.doi.org/10.1016/j.esd.2012.06.006

advantage and the partnership agreement was tailored to meet the needs of the companies (Margolis et al., 2006). For example at the a-Si team meetings, companies presented private information on a needto-know basis only and it was NREL's responsibility to monitor meetings to ensure that no party was a passive participant acting as a free rider $^{6}$. Before 2006, it was difficult to encourage companies to report important developments because of the fear of losing IP. Thus, in 2006, the quarterly reports were no longer open for all parties to see, but kept private between the company and NREL. ${ }^{7}$ In general, it was felt that firms within the TFPP would only be willing to share IP if it was guaranteed to benefit them in the long term. By making the sharing in the partnership worthwhile and beneficial to the research being conducted while still protecting IP, companies were prepared to share some of their information (Margolis et al., 2006). However, there were some larger, less-flexible firms that were not interested in participating in the partnership unless they had more formal rules protecting IP.

A recent example developed by a coalition of twenty educational institutions and companies in Canada can illustrate how such a business model works in practice. Due to the combination of a new large feed-in-tariff for PV in Ontario driving an enormous increase in PV deployment and the historic relatively intense snow in Canada, there is a concern in the local industry on the effects of snow cover on PV yield. Developers in particular are interested in the optimization of systems. There have been very few comprehensive studies published in the open literature, which attempt to quantify the effects of snowfall on PV output, and none which provide universally applicable estimations of snow related losses (Andrews and Pearce, 2012). The semi-complete studies that have been done are generally carefully guarded as post-competitive work as PV systems have been developed for decades. In order to overcome this challenge and provide useful information that will be available for all developers and systems owners in Canada an open-source PV snow study has been initiated (Pearce, et al., 2012). All of the companies participating in the study donated equipment to be tested under the following two key guidelines: 1) At the completion of the study, the University will provide measurements and analysis of the data collected from the modules donated by the Company for the Company, with the understanding that the final results of the study will be made publicly available; and (2) At the Company's discretion, the University agrees to refer to the results during the study on the Company's products in generalized terms in such a way as to make the Company's products non-identifiable in the public realm. These two clauses allow an open generalizable model to be created by the results that will benefit the companies and the public, while at the same time protecting all of the participating companies from what could be embarrassing results. It should be pointed out that none of the companies were either able or willing to single-handedly fund such a comprehensive study on their own, but working collectively under a carefully designed weave of MOUs the study was able to be created and is currently underway (Andrews and Pearce, 2012).

Coggeshall and Margolis recently completed an exhaustive review the experience of 14 U.S. consortia and 4 European consortia focused on PV manufacturing, testing, and R\&D (2010). The NREL report, which categorizes the 18 consortia into three groups (university-led, industry-led, and manufacturing and testing facilities consortia), found the benefits include: i) developing an educated PV workforce, driving innovative research, and supporting interactive collaborations via university led partnerships, ii) offering an open forum to identify best practices, promoting collaborative $R \& D$

\footnotetext{
${ }^{6}$ Ibid

${ }^{7}$ Ibid.
} 
Published as: A. J. Buitenhuis and J. M. Pearce, "Open-Source Development of Solar Photovoltaic Technology", Energy for Sustainable Development, 16, pp. 379-388 (2012). DOI: http://dx.doi.org/10.1016/j.esd.2012.06.006

projects based on shared costs and benefits, and developing industry standards and industry road mapping in corporation led partnerships; iii) reducing development costs and times, and mitigating technology risks for potential investors in shared PV manufacturing and testing facilities (Coggeshall and Margolis, 2010). This compilation was conducted to guide the U.S. DOE's Solar Energy Technologies Program as it prepares to initiate a new cost-shared R\&D effort on PV manufacturing. Clearly the U.S. government in addition to the members of the 18 consortia highlighted in the report has already identified the value of moving to a more open-source approach in the PV sector.

\subsection{Franchise Model}

The possibility that a competitor might use, improve upon, manufacture at a lower cost and take over some of the market of a product is a barrier for a firm to open-source its IP. If products were openly designed, firms would have no guarantee that their R\&D costs would be repaid by the profits of a product. However, companies could share their research if they were guaranteed to have monopoly access to a particular market. They could have geographical boundaries within which they would sell products without direct competition. This would give them the opportunity to collaborate with other firms and improve R\&D of new and improved products within a specific technology class.

A franchising system is used to create geographical boundaries for a specific industry. Within a franchise, the franchisor enters an agreement which allows the franchisee to market products and use trademarks in exchange for the payment of a franchise fee (Smyth et al., 2007). Figure 5 shows a structure for the solar industry based on the franchise model. For a franchise within the solar industry, the franchisor would be the turnkey equipment supplier, while the franchisees would be module manufacturers. The franchise agreement would ensure that the supplier would not grant more than one manufacturer for one territory, and the manufacturer would agree to not do business outside of their own territory. The agreement would also stipulate the management of IP; manufacturers would open their research developments to others in the franchise, as well as to the supplier. This sharing could be coordinated through the supplier as a centralized body, where manufacturers submit reports and attend meetings. There could also be collaboration among the manufacturers using online tools such as www.myexperiment.org. The supplier would benefit from access to research and data from manufacturers, enabling them to improve their products more quickly and develop their technologies. Manufacturers would benefit from the ability to access the research of other manufacturers, and the increased rate of innovation and quality of products would make them more competitive with other manufacturers outside of the franchise. The benefits of open design would be realized only internally, within the franchise.

One challenge with this model is that it is difficult for the franchisor to set up geographic territories for different manufacturers. Although it is trivial to control the actual location of a manufacturing plant installation to allow a local monopoly of a specific type of solar cell (and this is already the practice in some of the turnkey suppliers), creating boundaries within which different manufacturing firms must be limited to sell their product must be done carefully so that the firms are able to be successful. While geographic boundaries for manufacturing guarantee some transportation cost advantages, these may not overcome potential cost savings from reselling of other franchisee products in a given region. The boundaries must take into account viability of area to capture sunlight, regional or national programs in place to encourage PV deployment, existing manufacturers in the area, and commercial and public interest in PV. 
Published as: A. J. Buitenhuis and J. M. Pearce, "Open-Source Development of Solar Photovoltaic Technology", Energy for Sustainable Development, 16, pp. 379-388 (2012). DOI: http://dx.doi.org/10.1016/j.esd.2012.06.006

\subsection{Secondary Supplier Model}

There is potential to create openness within one specific industry by leveraging the power and needs of a supplier to that industry. In general, the secondary supplier model could be used in cases where a secondary industry would benefit highly from the growth of the primary industry. Encouraging the opening of design within the primary industry would be in the best interest of the secondary industry since the opening would increase the speed of the primary industry's growth, and thus the opportunity for the secondary industry to profit. One application of the secondary supplier model as applied to the solar industry is shown in Figure 6. The dotted arrows show that the secondary industry firm will openly share some IP with other players within the industry. Sharing would occur through publishing research in scientific journals, on new sites like openresearch.org, or on the firm's website to be accessed by primary industry firms. As the body of open research grows, a database could be created as a depository for all research opened by any firms within the industry. Each firm with open research could create its own database, or the database could be maintained by open access sites like myexperiment.org, or funded by relevant government agencies. This can be examined by looking at the encapsulation market with the PV industry and DuPont.

DuPont, a large science and technology company with revenues in 2008 of US $\$ 30.5$ billion, is a major supplier for manufacturers in the thin film industry (DuPont, 2009a). DuPont Photovoltaic Solutions is the branch of DuPont in charge of materials used in PV products such as encapsulants, front and back sheets, and thin film substrates, and makes up a large part of the market share. According to Photon International, between August 2006 and 2007, DuPont supplied almost every module manufacturer with polyvinyl fluoride (or Tedlar) used in thin film module back sheets (Schmela, 2007). DuPont PV Solutions is able to dominate the market through close R\&D relationships with their client PV manufacturers. In May 2009, DuPont opened a research facility in China focusing on module manufacturing, PV metallurization, and reliability testing (DuPont, 2009b). In July 2009, DuPont and the U.S. DOE jointly funded a US $\$ 9$ million research program focusing on moisturerepelling protective film for thin film PV modules (DuPont, 2009c). Much of this research is part of DuPont's efforts to create markets for its products. As an encapsulant manufacturer, creating applications that utilize its products is essential to business. In keeping with DuPont's focus on proprietary knowledge, processes and products are always patented to maintain dominance within the market. Often DuPont does not utilize the patents itself, but will license them out to manufacturers who use DuPont's products in their processes (for example, see DuPont, 2009d).

Using principles of open design DuPont could catalyze a novel shift in IP. This might happen in the solar PV industry if all IP not directly related to DuPont's own encapsulants was commercialized externally through open-source methods. Due to their extensive research of thin film PV products, DuPont patents not only encapsulant materials to be used in a module, but also design processes and products that would use this material within it. Direct IP, related to DuPont's products would be proprietary, but indirect IP relating to processes that are not part of DuPont's operations could be published openly. However, this would only be beneficial to DuPont if profits accrued from the rapid growth of the PV industry were significantly more than the profits DuPont normally receives through its usual method of licensing out patents that utilize their products. With predictions that the thin film PV market size will grow from $\$ 30$ million to $\$ 70$ million by 2013 (DuPont, 2009d) and with DuPont predicting a tripling of sales related to the PV market to over $\$ 1$ billion by 2012 (DuPont, 2009b), 
Published as: A. J. Buitenhuis and J. M. Pearce, "Open-Source Development of Solar Photovoltaic Technology", Energy for Sustainable Development, 16, pp. 379-388 (2012). DOI: http://dx.doi.org/10.1016/j.esd.2012.06.006

licensing revenues will not be significant compared to the sales of materials. Therefore, openly published patents would be more favorable for DuPont financially since innovations could quickly disseminate spurring industry growth. In turn, industry growth would only help DuPont due to the large stake in the thin film PV industry held by the company. In addition to these advantages, DuPont would benefit by being seen by its clients as leading in innovation and idea development. As an added incentive, DuPont may be able to leverage funding from government agencies by promoting open research if governments are interested in open-source design (Revkin and Galbraith, 2009).

\subsection{Completely Open-Source Design}

The trend towards the dominance of open-source software is clear because of the overwhelming benefits (Dalle and Jullien, 2003; Mulgan et al., 2005; DiBona et al. 1999) and this section examines how the solar PV industry might function under a large-scale and aggressive shift to fully open design principles. Consider a solar market where all research was published openly for any firms to use, as shown in Figure 7. A firm might contribute to the research of another firm, while using external research to enhance their own products. There would be no patenting of PV designs or processes, and no restrictive licensing. Firms would publish work through open licensing, which would allow others to access research and ensure that all new ideas stemming from the original research were also licensed openly. All universities, turnkey suppliers, and manufacturers would be part of a research network. If one region of the world were to shift radically to an open-source PV industry, it would still remain competitive with other regions that were using closed development, because the technology in the open region would advance more quickly and be of a higher quality.

Such an environment could be similar to a 'perfect market', where all firms have the same technologies and thus no leverage. As Gabriel (2007) describes in his vision for a completely 'open software world', many firms would have access to enter the market, because barriers caused by the lack of IP would be nonexistent. Students in academic institutions would also have access to all solar PV research, allowing them to become familiar with technologies while studying, thus enhancing their understanding of PV technology and future employability. Solar PV could compete with entirely different industries, such as the coal industry, for dominance in the electricity-producing market.

For this large-scale, collaborative research initiative to be sustained, a major shift in the solar PV industry and a new strategy for profit-making would be required. One way that this shift might occur is through a large-scale government-led initiative to drive the development of solar PV research. The Apollo Project, which focused on landing a 'man on the moon' is an example of a large-scale research collaboration between many scientists and experts on topics that are both very challenging and strategically important (Tuomi, 2005). Climate change and world poverty are both global problems, which will require a serious commitment. Direct subsidization of the challenges enhance the technological growth but are unlikely to succeed in solving the larger problems alone (Yang and Oppenheimer, 2007). Therefore, the open-source PV approach could overcome this challenge using a from like the United Nations Framework Convention on Climate Change. Such an agreement could include a clause directing all research conducted by government labs, universities and firms to be published openly. Government could even incentivize firms to innovate by paying rewards for putting IP in the public domain or by sponsoring firms to open research.

An aggressive shift to fully open-source design in the PV industry and a complete rejection of proprietary research would meet substantial barriers. The largest barrier to such a drastic shift in 
Published as: A. J. Buitenhuis and J. M. Pearce, "Open-Source Development of Solar Photovoltaic Technology", Energy for Sustainable Development, 16, pp. 379-388 (2012). DOI: http://dx.doi.org/10.1016/j.esd.2012.06.006

ideology is the lack of political will to make the shift. Such a large government initiative would require considerable international public support. Often the public does not feel ownership over international agreements, and therefore, their implementation is not always successful (Barrett and Stavins, 2003). An examination of public opinion regarding climate change shows that while there is a general perception that climate change is important to the US, there is a very poor public understanding of the causes and consequences of global climate change (Lorenzoni and Pidgeon, 2006). Currently, the public would need to have a better understanding of the details of climate change, international development and the potential of PV technology. Attaining global public support for such a drastic shift would prove difficult in the current political climate.

\section{Discussion}

The business models summarized in Table 1 describe four methods through which open principles could be included in the solar PV industry. Overall, each business model increases the level of openness within the thin film PV industry and each one could be applied depending on the circumstances governing a specific company or the global political climate.

The partnership model is the most flexible model in that depending on the firms interested, the funding body, and the state of the industry at a given time, the partnership could be made as open or as closed as desired. Both the partnership model and the franchise model allow for the sharing of not only IP or research, but also equipment and testing facilities. These models would be ideal for companies starting up or beginning to grow within the industry, as they would reduce initial R\&D costs. This type of company has the most to gain with the first two models because they would greatly accelerate the company's learning curve and enhance its understanding of the PV markets. This would allow more companies to begin manufacturing solar PV modules and allow for faster dissemination of best practices. The Secondary Supplier model is more suited to larger companies with more experience. However, such a company's involvement in open-source design methods would be different. With large and rich $R \& D$ programs, large companies are free to pursue external pathways to commercialize, publish and market ideas and products to enhance the PV industry as a whole, and, in turn, increase their opportunity to profit from that industry.

The Completely Open-Source model examines the results of a critical mass of companies practicing different forms of open design and a mentality shift in the solar industry. No longer would firms have a focus on proprietary knowledge and IP protection; a gift culture would be created where the best and most reliable firms would be known for their open contributions to the technical knowledge of the field. It should be pointed out here that the gift culture would be one of information about a capital intensive hardware industry and not the hardware itself. This process could be created more quickly through large, government-led initiatives.

These four business models are examples of ways in which a new method of innovation, open design, could be implemented in the solar PV industry. It is clear that the benefits of increased openness although accruing to each individual company would be greater for society as a whole. This indicates future work is necessary to look at policy instruments at the state, national and international levels to encourage open strategies in PV development for the well established benefits of the technology (Pearce, 2002).

\section{Conclusions}


Published as: A. J. Buitenhuis and J. M. Pearce, "Open-Source Development of Solar Photovoltaic Technology", Energy for Sustainable Development, 16, pp. 379-388 (2012). DOI: http://dx.doi.org/10.1016/j.esd.2012.06.006

All methods of innovation to advance and improve solar PV technologies must be examined in order to maximize the dissemination and use of solar PV in both the developing and developed world. The benefits of an open-source approach to development are now well established in software and the concepts would have a similar effect on the solar PV field as new methods of innovation would drive the field forward. This paper has highlighted open-source concepts and business models in order to allow open-source principles to be utilized to improve the rate of innovation within solar PV research. In the existing business environment PV companies can develop and share research through partnerships and franchise programs. Open-source research could also be promoted by secondary industries interested in the success of solar PV technologies or by governments interested in long-term energy security and climate change mitigation. A completely open-source model has the largest benefit to the PV industry as a whole, but demands a shift in mentality to allow solar PV to develop at an even faster rate and become an important factor in the move toward sustainable energy development.

\section{Acknowledgements}

This authors would like to thank B. von Roedern, employees of DuPont, K. Branker, A. Brennan, K. Buitenhuis, R. Kenney, C. Law, U. Mushtaq, E. Shackles and L. Wiginton for helpful discussions. This work was supported by NSERC. 
Published as: A. J. Buitenhuis and J. M. Pearce, "Open-Source Development of Solar Photovoltaic Technology", Energy for Sustainable Development, 16, pp. 379-388 (2012). DOI: http://dx.doi.org/10.1016/j.esd.2012.06.006

\section{Tables and Figures Captions}

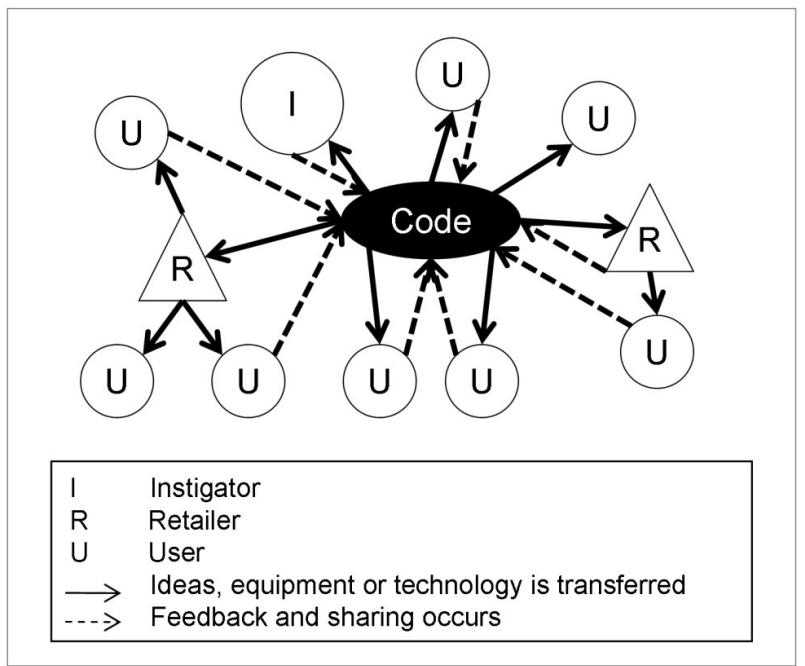

Figure 1: Open software development map

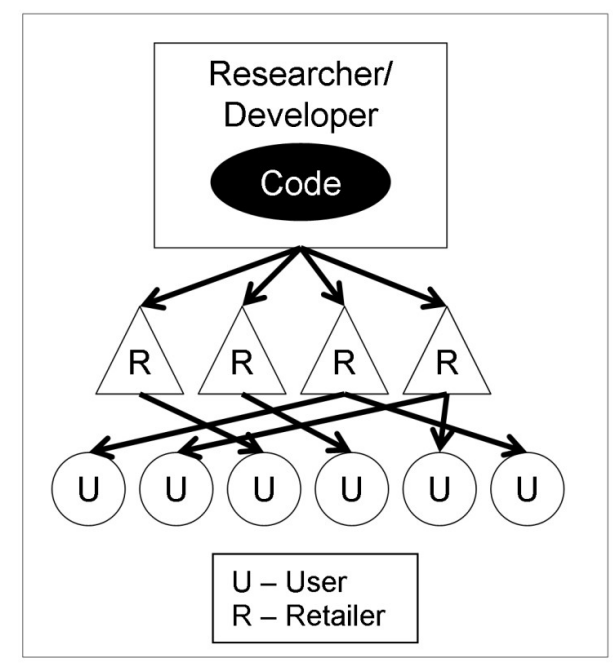

Figure 2: Proprietary software development map 
Published as: A. J. Buitenhuis and J. M. Pearce, “Open-Source Development of Solar Photovoltaic Technology”, Energy for Sustainable Development, 16, pp. 379-388 (2012). DOI: http://dx.doi.org/10.1016/j.esd.2012.06.006

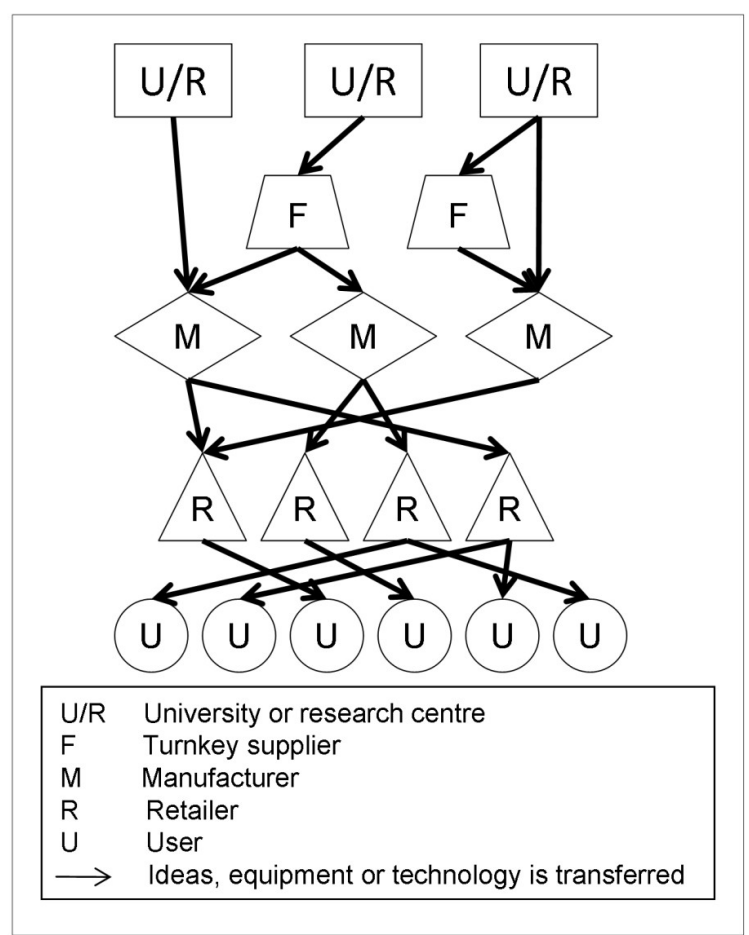

Figure 3: Conventional solar photovoltaic industry map

Figure 4: Partnership model

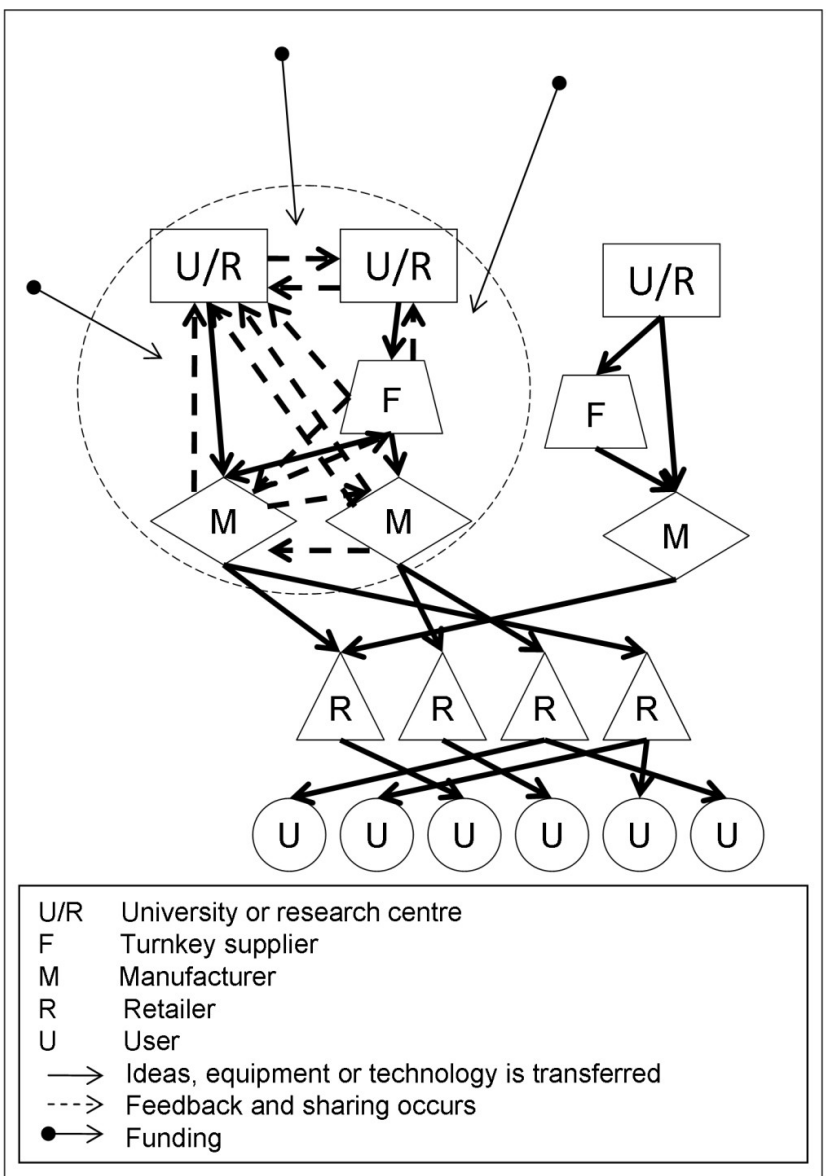


Published as: A. J. Buitenhuis and J. M. Pearce, “Open-Source Development of Solar Photovoltaic Technology”, Energy for Sustainable Development, 16, pp. 379-388 (2012). DOI: http://dx.doi.org/10.1016/j.esd.2012.06.006

Figure 5: Franchise model

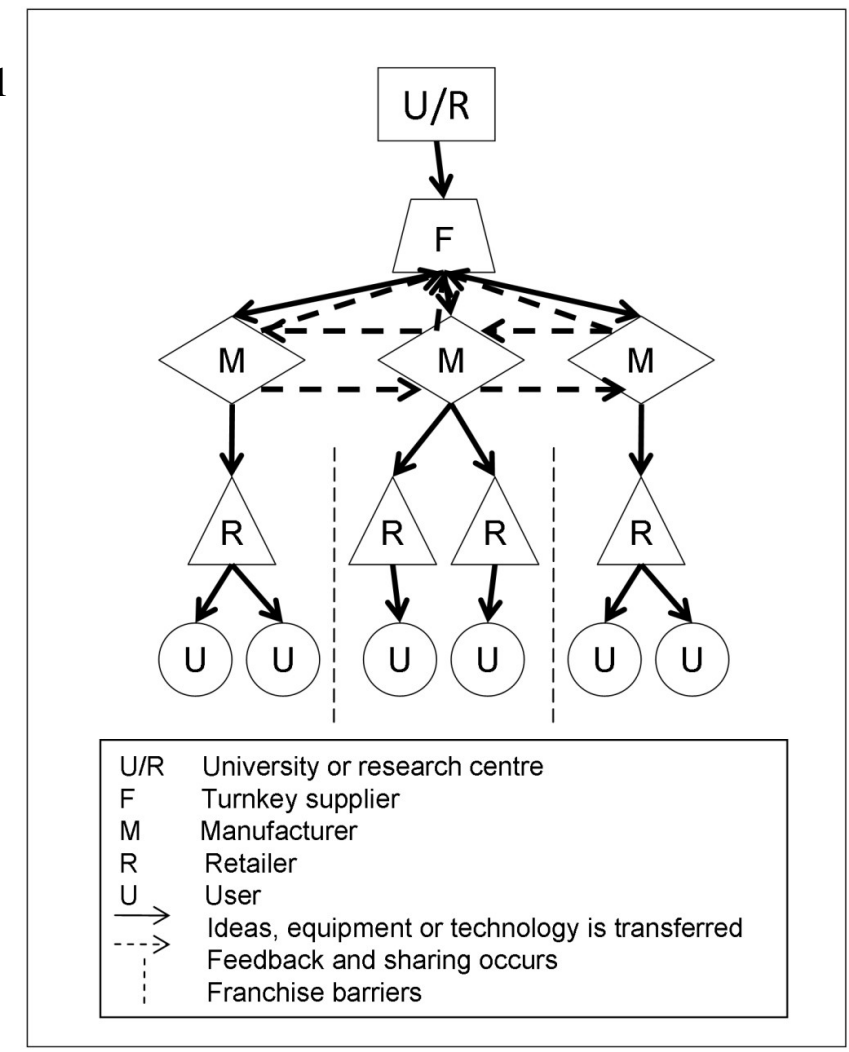

Figure 6: Secondary supplier model

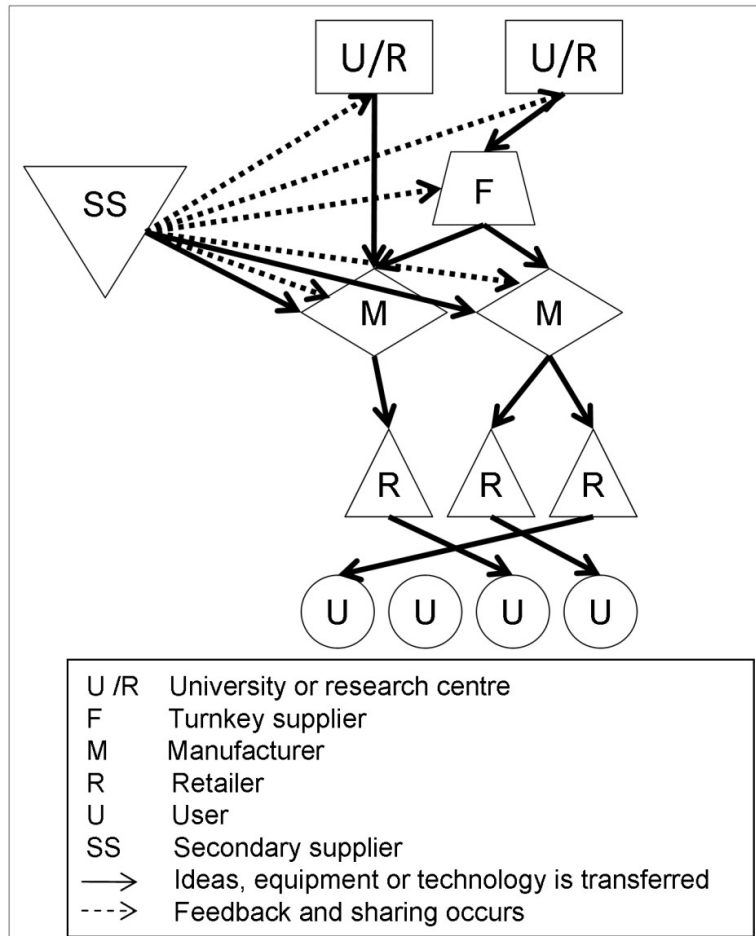


Published as: A. J. Buitenhuis and J. M. Pearce, “Open-Source Development of Solar Photovoltaic Technology”, Energy for Sustainable Development, 16, pp. 379-388 (2012). DOI: http://dx.doi.org/10.1016/j.esd.2012.06.006

Figure 7: Complete open-source model

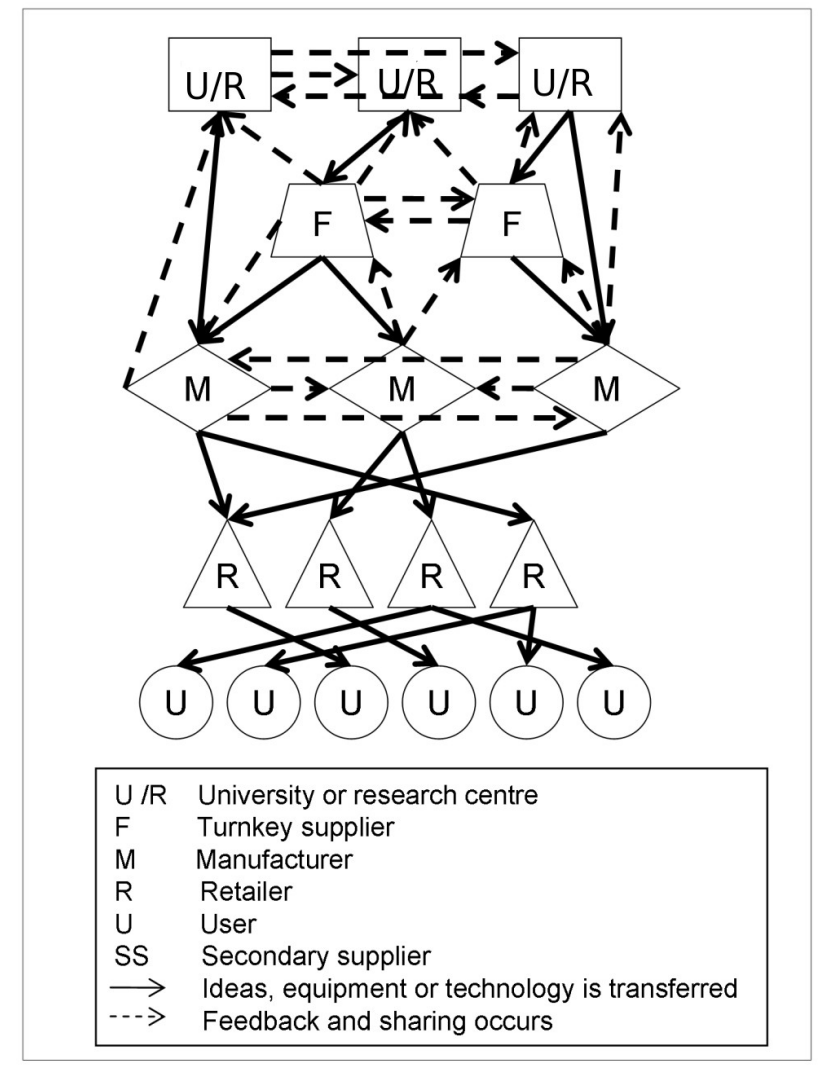


Published as: A. J. Buitenhuis and J. M. Pearce, “Open-Source Development of Solar Photovoltaic Technology”, Energy for Sustainable Development, 16, pp. 379-388 (2012). DOI: http://dx.doi.org/10.1016/j.esd.2012.06.006

\begin{tabular}{|c|c|c|c|c|c|c|}
\hline Model & Description & Funding & $\begin{array}{l}\text { Open Source } \\
\text { Application }\end{array}$ & $\begin{array}{l}\text { Example } \\
\text { from } \\
\text { Solar } \\
\text { Industry }\end{array}$ & Strengths & Challenges \\
\hline $\begin{array}{l}\text { Partnership } \\
\text { Model }\end{array}$ & $\begin{array}{l}\text { Firms make an } \\
\text { agreement to } \\
\text { partner and share } \\
\text { IP within the } \\
\text { partnership. }\end{array}$ & $\begin{array}{l}\text { Governments or } \\
\text { private industry } \\
\text { fund firms in } \\
\text { partnership. }\end{array}$ & $\begin{array}{l}\text { Technologies } \\
\text { are developed } \\
\text { through } \\
\text { sharing IP and } \\
\text { resources with } \\
\text { members. }\end{array}$ & TFPP & $\begin{array}{l}\text { Works well when } \\
\text { partnership } \\
\text { agreements and } \\
\text { funding is long-term, } \\
\text { and when } \\
\text { participants are small } \\
\text { or medium-size } \\
\text { firms. }\end{array}$ & $\begin{array}{l}\text { It is more } \\
\text { difficult to } \\
\text { attract large } \\
\text { industry players } \\
\text { when their IP is } \\
\text { well- } \\
\text { established. }\end{array}$ \\
\hline $\begin{array}{l}\text { Franchise } \\
\text { Model }\end{array}$ & $\begin{array}{l}\text { Turnkey supplier } \\
\text { acts as franchisor } \\
\text { to limit the market } \\
\text { access } \\
\text { manufacturers } \\
\text { geographically. }\end{array}$ & $\begin{array}{l}\text { Manufacturers } \\
\text { (franchisees) } \\
\text { pay a fee to } \\
\text { turnkey } \\
\text { suppliers } \\
\text { (franchisors). }\end{array}$ & $\begin{array}{l}\text { Technologies } \\
\text { are developed } \\
\text { through } \\
\text { sharing IP and } \\
\text { resources with } \\
\text { members. }\end{array}$ & Oerlikon & $\begin{array}{l}\text { Works well when } \\
\text { partnership } \\
\text { agreements and } \\
\text { funding is long-term, } \\
\text { and when } \\
\text { participants are small } \\
\text { or medium-size } \\
\text { firms. }\end{array}$ & $\begin{array}{l}\text { Anti-trust issues } \\
\text { could easily } \\
\text { arise. It is } \\
\text { challenging to } \\
\text { set up } \\
\text { geographical } \\
\text { boundaries that } \\
\text { are secure and } \\
\text { profitable. }\end{array}$ \\
\hline $\begin{array}{l}\text { Secondary } \\
\text { Industry } \\
\text { Model }\end{array}$ & $\begin{array}{l}\text { Firms in a } \\
\text { secondary } \\
\text { industry promote } \\
\text { open source } \\
\text { research in a } \\
\text { primary industry } \\
\text { in order to expand } \\
\text { the primary } \\
\text { industry. }\end{array}$ & $\begin{array}{l}\text { Secondary firm } \\
\text { funds open } \\
\text { source research } \\
\text { directly. }\end{array}$ & $\begin{array}{l}\text { IP that a } \\
\text { secondary } \\
\text { industry firm } \\
\text { generates } \\
\text { regarding the } \\
\text { primary } \\
\text { industry is } \\
\text { openly } \\
\text { published. }\end{array}$ & DuPont & $\begin{array}{l}\text { Works when a firm } \\
\text { with a majority of the } \\
\text { supplier market share } \\
\text { will agree to explore } \\
\text { open options for } \\
\text { commercialization of } \\
\text { IP. }\end{array}$ & $\begin{array}{l}\text { It will not work } \\
\text { as well if the } \\
\text { secondary } \\
\text { industry firm is } \\
\text { not a large } \\
\text { market force. }\end{array}$ \\
\hline $\begin{array}{l}\text { Fully Open } \\
\text { Model }\end{array}$ & $\begin{array}{l}\text { Shift in the } \\
\text { industry so all } \\
\text { organizations } \\
\text { collaborate and } \\
\text { share research. }\end{array}$ & $\begin{array}{l}\text { Governments or } \\
\text { international } \\
\text { bodies fund } \\
\text { entire industry. }\end{array}$ & $\begin{array}{l}\text { All research is } \\
\text { open source. }\end{array}$ & $\begin{array}{l}\text { Could } \\
\text { begin to } \\
\text { occur in } \\
\text { the solar } \\
\text { industry }\end{array}$ & $\begin{array}{l}\text { Research would } \\
\text { move quickly, } \\
\text { barriers to enter the } \\
\text { market would be } \\
\text { reduced and firms } \\
\text { would not be limited } \\
\text { by any IP protections. }\end{array}$ & $\begin{array}{l}\text { It is difficult to } \\
\text { gain political } \\
\text { support needed } \\
\text { to fund such a } \\
\text { change in } \\
\text { research and } \\
\text { business } \\
\text { practices. }\end{array}$ \\
\hline
\end{tabular}

Table 1: Summary of open-source business models as they apply to the solar PV industry 
Published as: A. J. Buitenhuis and J. M. Pearce, "Open-Source Development of Solar Photovoltaic Technology", Energy for Sustainable Development, 16, pp. 379-388 (2012). DOI: http://dx.doi.org/10.1016/j.esd.2012.06.006

\section{References}

Andrews, R.,Pearce, J.M. 2012. Prediction of Energy Effects on Photovoltaic Systems due to Snowfall Events. Proceedings of the $38^{\text {th }}$ IEEE Photovoltaics Specialists Conference (in press).

Antelman, K., 2004. Do Open-Access Articles Have a Greater Research Impact? College \& Research Libraries 65, 372-382.

Barrett, S., Stavins, R., 2003. Increasing Participation and Compliance in International Climate Change Agreements. International Environmental Agreements: Politics, Law \& Economics 3, 349-376.

Benkler, Y., 2004. Commons-Based Strategies and the Problems of Patents. Science 305, 1110-1111.

Bergquist, M., Ljungberg J., 2001. The power of gifts: organizing social relationships in open source communities. Information Systems Journal 11, 305-320.

Branker, K., Pathak, M. J.M., Pearce, J. M. 2011. A Review of Solar Photovoltaic Levelized Cost of Electricity, Renewable \& Sustainable Energy Reviews (in press). DOI:

10.1016/j.rser.2011.07.104

Branstetter, L.G., 2004. Do Stronger Patents Induce More Local Innovation? J Int Economic Law 7, 359-370.

Bonaccorsi, A., Rossi, C., 2003. Why Open Source software can succeed. Research Policy 32, 12431258.

Bonaccorsi, A., Rossi, C., Giannangeli, S. 2004. Adaptive Entry Strategies under Dominant Standards Hybrid Business Models in the Open Source Software Industry. SSRN Journal doi:10.2139/ssrn.519842

Bord, R.J., O'Connor, R.E., Fisher, A., 2000. In what sense does the public need to understand global climate change? Public Understanding of Science 9, 205-218.

Bruns, B., 2001. Open sourcing nanotechnology research and development: issues and opportunities. Nanotechnology 12, 198-210.

Buitenhuis, A. J., Zelenika, I., Pearce, J. M. 2010. Open Design-Based Strategies to Enhance Appropriate Technology Development, Proceedings of the $14^{\text {th }}$ Annual National Collegiate Inventors and Innovators Alliance Conference : Open, March 25-27th 2010, pp. 1-12.

Coggeshall, C., Margolis, R.M. 2010. Consortia Focused on Photovoltaic R\&D, Manufacturing, and Testing: A Review of Existing Models and Structures, National Renewable Energy Laboratory Technical Report, NREL/TP-6A2-47866.

Dalle, J.-M., Jullien, N., 2003. 'Libre’ software: turning fads into institutions? Research Policy 32, 111.

DiBona, C., Ockman,S., Stone, M. (Eds.) 1999. Open Sources: Voices from the Open Source Revolution. O'Reilly \& Associates, Inc.

DuPont, 2009a. DuPont Home Page. At <http://www2.dupont.com/DuPont_Home/en_US/index.html>, last accessed 17.07.2009.

DuPont, 2009b. DuPont Opens New Photovoltaic Technical Center in China. May 4, 2009. At < http://www2.dupont.com/Photovoltaics/en_US/news_events/article20090504.html>, last acessed 27.07.2009.

DuPont, 2009c. DuPont, U.S. Dept. of Energy Partner on Innovative Thin Film Solar Program. July 1, 2009. At < http://www2.dupont.com/Photovoltaics/en_US/news_events/article20090701.html>, last accessed 27.07.2009.

DuPont, 2009d. DuPont Expects Continued Revenue Growth in Global Photovoltaic Market. March 17, 2009. At 
Published as: A. J. Buitenhuis and J. M. Pearce, "Open-Source Development of Solar Photovoltaic Technology", Energy for Sustainable Development, 16, pp. 379-388 (2012). DOI: http://dx.doi.org/10.1016/j.esd.2012.06.006

<http://www2.dupont.com/Photovoltaics/en_US/news_events/article20090317.html>, last accessed 17.07.2009.

Einstein Archives Online, 2003. Einstein Archives Online - Archival Database. At < http://www.alberteinstein.info/database/>, last accessed 24.07.2009.

Fink, M. 2002. Business and Economics of Linux and Open Source. Prentice Hall Professional Technical Reference.

Foley, G. 1995. Photovoltaic Applications in Rural Areas of the Developing World. World Bank Publications.

Gallini, N.T., 2002. The Economics of Patents: Lessons from Recent U.S. Patent Reform. The Journal of Economic Perspectives 16, 131-154.

Garud, R., Kumaraswamy, A., 1993. Changing Competitive Dynamics in Network Industries: An Exploration of Sun Microsystems' Open Systems Strategy. Strategic Management Journal 14, 351-369.

Green, M.A. 2003. Third Generation Photovoltaics: Advanced Solar Electricity Generation, SpringerVerlag: Berlin.

Hecker, F. 1999. Setting up shop: The business of open-source software. IEEE Software 16, 45-51.

Hedman, J., Kalling, T. 2003. The business model concept: theoretical underpinnings and empirical illustrations. European Journal of Information Systems, 12, 49-59.

Heller, M.A., Eisenberg, R.S., 1998. Can Patents Deter Innovation? The Anticommons in Biomedical Research. Science 280, 698-701.

Hoffert, M.I., Caldeira, K., Benford, G., Criswell, D.R., Green, C., Herzog, H., Jain, A.K. et al., 2002. Advanced Technology Paths to Global Climate Stability: Energy for a Greenhouse Planet. Science 298, 981-987.

Ilic, M., Black, J. \& Prica, M. 2007. Distributed electric power systems of the future: Institutional and technological drivers for near-optimal performance. Electric Power Systems Research 77, 11601177.

International Energy Agency Photovoltaic Power Systems Programme (IEA PVPS), 2009. PVPS Annual Report 2009: Implementing Agreement on Photovoltaic Power Systems. At <http://www.iea-pvps.org/ar/ar09/Final\%20AR\%20for\%20Web\%202009/rep_ar09.pdf> last accessed 21.09.2010.

International Energy Agency (IEA). 2010. Technology Roadmap: Solar photovoltaic energy. At $<$ http://www.iea.org/papers/2010/pv_roadmap.pdf> last accessed 21.09.2010.

Jaffe, A.B., 2000. The U.S. patent system in transition: policy innovation and the innovation process. Research Policy 29, 531-557.

Jäger-Waldau, A. 2011. PV Status Report 2011: Research, Solar Cell Production and Market Implementation of Photovoltaics, 2011 European Commission, DG Joint Research Centre, Institute for Energy and Transport, Renewable Energy Unit Via Enrico Fermi; TP 450 I - 21027 Ispra (VA), Italia. At <http://re.jrc.ec.europa.eu/refsys/> last accessed 15. 9. 2011.

Kapczynski, A., Chaifetz, S., Benkler, Y., Katz, Z., 2005. Addressing Global Health Inequities: An Open Licensing Approach for University Innovations. Berkley Technology Law Journal 20, 1031-1114.

Kenny, R., Law, C., Pearce, J.M. 2010. Towards Real Energy Economics: Energy Policy Driven by Life-Cycle Carbon Emission, Energy Policy 38, 1969-1978.

Keshner, M.S., Arya, R., 2004. Study of Potential Cost Reductions Resulting from Super-Large-Scale 
Published as: A. J. Buitenhuis and J. M. Pearce, "Open-Source Development of Solar Photovoltaic Technology", Energy for Sustainable Development, 16, pp. 379-388 (2012). DOI: http://dx.doi.org/10.1016/j.esd.2012.06.006

Manufacturing of PV Modules. National Renewable Energy Laboratory final subcontract no. ADJ-3-33631-01 report.

Kogut, B., Metiu, A., 2001. Open-Source Software Development and Distributed Innovation. Oxford Review of Economic Policy 17, 248-264.

Krishnamurthy, S. 2005. “An Analysis of Open Source Business Models”, in Feller, J, Fitzgerald, B, Hissam, S, and Lakhani, K. (2005) (Eds) Perspectives on Free and Open Source Software, MIT Press, Cambridge.

Lakhani, K.R., von Hippel, E., 2003. How open source software works: "free" user-to-user assistance. Research Policy 32, 923-943.

Lerner, J., Tirole, J., 2005. The Scope of Open Source Licensing. Journal of Law, Economics, \& Organization 21, 20-56.

Lorenzoni, I., Pidgeon, N., 2006. Public Views on Climate Change: European and USA Perspectives. Climatic Change 77, 73-95.

Mahadevan, B. (2000) Business models for internet-based ecommerce: an anatomy, California Management Review, 42(4), 55-69.

Manz, D., Schelenz, O., Chandra, R., Bose, S., de Rooij, M., Bebic, J. 2008. Enhanced Reliability of Photovoltaic Systems with Energy Storage and Controls. National Renewable Energy Laboratory Subcontract Report, NREL/SR-581-42299.

Margolis, R., Mitchell, R., Zweibel, K., 2006. Lessons Learned from the Photovoltaic Manufacturing Technology/PV Manufacturing R\&D and Thin-Film PV Partnership Projects. National Renewable Energy Lab Technical Report NREL/TP-520-39780.

Maurer, S.M., Rai, A., Sali, A., 2004. Finding Cures for Tropical Diseases: Is Open Source an Answer? PLoS Medicine 1, 183-186.

Mazzoleni, R., Nelson, R.R., 1998. The benefits and costs of strong patent protection: a contribution to the current debate. Research Policy 27, 273-284.

Meier, J., Dubail, S., Cuperus, J., Kroll, U., Platz, R., Torres, P., Anna Selvan, J.A., et al. 1998. Recent progress in micromorph solar cells. Journal of Non Crystalline Solids 227, 1250-1256.

Mockus, A., Fielding, R.T., Herbsleb, J.D., 2002. Two case studies of open source software development: Apache and Mozilla. ACM Trans. Softw. Eng. Methodol. 11, 309-346.

Mulgan, G., Steinberg, T., Salem, O., 2005. Wide Open: Open Source Methods and their Future Potential. Demos, London.

Mushtaq, U., Pearce, J.M. 2012. Open Source Appropriate Nanotechnology. in Maclurcan, D.,

Radywyl, N. (Eds.), Nanotechnology and Global Sustainability, CRC Press: Boca Raton, 191-213.

National Renewable Energy Lab, 2008. NREL: Thin Film Partnership Program - About the Thin Film Partnership Program. At <http://www.nrel.gov/pv/thin_film>, last accessed 20/07/2009.

O'Reilly, T. 2007. What is Web 2.0: Design Patterns and Business Models for the Next Generation of Software. Communications \& Strategies, 65(1), 17-37.

Papathanasiou, O., 2009. The European Patent Office revokes Oerlikon's thin-film patent. Photon International 5, 44-46.

Pearce, J.M., 2002. Photovoltaics - a path to sustainable futures. Futures 34, 663-674.

Pearce, J.M., 2008. Industrial symbiosis of very large-scale photovoltaic manufacturing. Renewable Energy 33, 1101-1108.

Pearce, J.M., Harris, P.J., 2007. Reducing greenhouse gas emissions by inducing energy conservation and distributed generation from elimination of electric utility customer charges, Energy Policy, 
Published as: A. J. Buitenhuis and J. M. Pearce, “Open-Source Development of Solar Photovoltaic Technology”, Energy for Sustainable Development, 16, pp. 379-388 (2012). DOI: http://dx.doi.org/10.1016/j.esd.2012.06.006

35, 6514-6525.

Pearce, J.M., Mushtaq, U., 2009. Overcoming Technical Constraints for Obtaining Sustainable Development with Open Source Appropriate Technology, in Science and Technology for Humanity (TIC-STH), 2009 IEEE Toronto International Conference, pp. 814-820.

Pearce, J. M., Babasola, A., Andrews, R. 2012. Open Solar Photovoltaic Systems Optimization, Proceedings of the 16th Annual National Collegiate Inventors and Innovators Alliance Conference, Open 2012, pp. 1-7.

Petrone, G., Spagnuolo, G., Teodorescu, R., Veerachary, M. \& Vitelli, M. 2008. Reliability Issues in Photovoltaic Power Processing Systems. IEEE Transactions on Industrial Electronics, 55(7), 2569-2580.

Pomerance, G.M., 2000. Business Models for Open Source Hardware Design. At $<$ http://pages.nyu.edu/ gmp216/papers/bmfosh-1.0.html>, last accessed 12.08.2009.

Pykäläinen, T., 2007. Model for profiting from software innovations in the new era in computing. Technovation 27, 179-193.

Raymond, E., 1999. The cathedral and the bazaar. Knowledge, Technology \& Policy 12, 23-49.

Revkin, A., Galbraith, K., 2009. Energy Chief Seeks Global Flow of Ideas - . Dot Earth Blogs, New York Times. At <http://dotearth.blogs.nytimes.com/2009/03/26/energy-chief-seeks-global-flowof-ideas/?pagemode=print $>$, last accessed 15.07.2009.

Schankerman, M., 1998. How valuable is patent protection? Estimates by technology field. The RAND Journal of Economics 29, 77-107.

Schmela, M., 2007. Market Survey on Laminators and Encapsulation Materials. Photon International 82007, 144-170.

Shah, A., Torres, P., Tscharner, R., Wyrsch, N., Keppner, H., 1999. Photovoltaic Technology: The Case for Thin-Film Solar Cells. Science 285, 692-699.

Sills, B. 2011. Solar May Produce Most of World's Power by 2060, IEA Says. Bloomberg. Aug 29, 2011. At <http://www.bloomberg.com/news/2011-08-29/solar-may-produce-most-of-world-spower-by-2060-iea-says.html> last accessed 15.09.2011.

Smyth, J.E., Soberman, D.A., Easson, A.J., 2007. The Law and Business Administration in Canada, 11th ed. Pearson Prentice Hall, Toronto.

Solarbuzz, 2009. Solarbuzz Reports World Solar Photovoltaic Market Grew to 5.95 Gigawatts in 2008. In <http://www.solarbuzz.com/Marketbuzz2009-intro.htm>, last accessed 18.07.2009.

Staebler, D. L., Wronski C.R., 1977. Reversible conductivity changes in discharge-produced amorphous Si. Applied Physics Letters 31, 292-294.

Stallman, R. 1999. Richard Stallman -- On "Free Hardware", Linux Today, Jun 22, 1999. In <http://www.linuxtoday.com/news_story.php3?ltsn=1999-06-22-005-05-NW-LF> last accessed 25.09.2010.

Torrance, A.W., Tomlinson, B., 2009. Patents and the Regress of Useful Arts. The Columbia Science and Technology Law Review 10, 130-168.

Tuomi, I., 2005. The Future of Open Source, in: Wynants, M., Cornelis, J. (Eds), How Open is the Future? VUB Brussels University Press, Brussels, Belgium, pp 429-459.

VLSI Research Inc. 2009. Photovoltaic Cell manufacturing equipment: Top-10 supplier ranking. At $<$ https://www.vlsiresearch.com/cms_pdf_upload/pdf_file_1233694471.pdf>, last accessed 17.07.2009.

Wronski, C.R, Pearce, J.M., Koval, R. J., Niu, X., Ferlauto, A. S., Koh, J. and Collins, R. W. 2002. 
Light Induced Defect Creation Kinetics in Thin Film Protocrystalline Silicon Materials and Their Solar Cells. Material Research Society Symposium Proceedings. 715, A13.4.

Wronski, C. R., Pearce, J.M., Deng, J., Vlahos, V., Collins, R.W., 2004. Intrinsic and Light Induced Gap States in a-Si:H Materials and Solar Cells - Effects of Microstructure. Thin Solid Films 451-452, 470-475.

Yang, C.-J., Oppenheimer, M., 2007. A “Manhattan Project” for climate change? Climatic Change 80, 199-204.

Zott, C., Amit, R., Massa, L. 2010. The Business Model: Theoretical Roots, Recent Developments, and Future Research. IESE Business School University of Navarra, Working Paper-862. 